\title{
PERLINDUNGAN HAK-HAK PEREMPUAN DAN ANAK DITINJAU DARI ASPEK HUKUM
}

\author{
Annisa Fitria, Melani Darman, Nia Puspita Hapsari \\ Fakultas Hukum, Universitas Esa Unggul, Jakarta \\ Jalan Arjuna Utara No 9 Kebon Jeruk, Jakarta - 11510 \\ annisa.fitria@esaunggul.ac.id
}

\begin{abstract}
Domestic violence (KDRT) is a violation of the law where the perpetrator can be convicted, the reasons for the perpetrator to commit domestic violence can be various, such as economic problems, and others. Many victims did not dare to report to the police because the perpetrators were still husband or wife and also people around them did not dare to help because they felt that th is was not their responsibility. The problem of bullying against children at school is a very concerning thing and is also prevalent. Children can be traumatized because they are given bullying from their friends and this can interfere with the child's development. Through this community service, it is hoped that the participants who participate can add insight and the acts of domestic violence and bullying should be stopped.
\end{abstract}

Keywords: legal protection, domestic violence (KDRT), child bullying

\begin{abstract}
Abstrak
Kekerasan dalam rumah tangga (KDRT) merupakan suatu pelanggaran hukum yang mana pelaku nya dapat dipidana, alas an pelaku melakukan KDRT bisa bermacammacam seperti masalah ekonomi, dan lain lain. Banyak korban yang tidak berani untuk melapor kepada pihak kepolisian dikarenakan pelaku masih berstatus suami atau istri dan juga orangorang yang berada disekitar nya tidak berani untuk ikut membantu dikarenakan merasa hal tersebut bukan tanggungjawabnya. Masalah bullying terhadap anak di sekolah merupakan hal yang sangat memprihatinkan dan juga marak terjadi. Anak bisa menjadi trauma karena diberikan bullying dari teman teman nya dan hal tersebut bisa sampai mengganggu perkembangan anak. Melalui pengabdian masyarakat ini diharapkan agar para peserta yang mengikuti bisa menambah wawasan dan perbuatan KDRT dan Bullying seyogyanya bisa dihentikan.
\end{abstract}

Kata kunci: perlindungan hukum, kekerasan dalam rumah tangga (KDRT), bullying anak

\section{Pendahuluan}

Kekerasan dalam rumah tangga (KDRT) adalah tindakan yang dilakukan di dalam rumah tangga baik oleh suami, istri, maupun anak yang berdampak buruk terhadap keutuhan fisik, psikis, dan keharmonisan hubungan sesuai yang terdapat dalam pasal 1 Undang-Undang Nomor 23 Tahun 2004 tentang Penghapusan Kekerasan dalam Rumah Tangga (UU PKDRT). Yang merupakan lingkup tindakan KDRT adalah perbuatan terhadap seseorang terutama perempuan, yang berakibat timbulnya kesengsaraan atau penderitaan secara fisik, seksual, psikologis, dan/atau penelantaran rumah tangga termasuk ancaman untuk melakukan perbuatan, pemaksaan, atau perampasan kemerdekaan secara melawan hukum dalam lingkup rumah tangga. Sebagian besar korban KDRT adalah kaum perempuan (istri) dan pelakunya adalah suami, walaupun ada juga korban justru sebaliknya, atau orang-orang yang tersubordinasi didalam rumah tangga itu.
Perlindungan hukum terhadap korban kekerasan dalam rumah tangga menurut UndangUndang Nomor 23 Tahun 2004 tentang Penghapusan Kekerasan dalam rumah tangga sangat dibutuhkan karena segala bentuk kekerasan, terutama kekerasan dalam rumah tangga, adalah pelanggaran hak asasi manusia dan kejahatan terhadap martabat kemanusiaan serta bentuk diskriminasi. Korban kekerasan fisik-psikis, seksual dan penelantaran mengalami penderitaan dan kerugian, sehingga perlu dilindungi hak-hak korban untuk memperoleh keadilan. Anak merupakan penerus bangsa maka dari itu anak tidak boleh sejak dini diberikan bullying baik secara fisik maupun mental karena akan mengganggu pertumbuhan anak. Penyebab bullying terhadap anak bisa terjadi macam-macam, bisa dilakukan di lingkungan sekolah, lingkungan bermain dan lain lain. Hal ini haruslah dihentikan dan perlunya edukasi terhadap masyarakat bahwa bullying itu bisa masuk kedalam kategori tindak pidana apabila unsur-unsur atau mens rea nya terpenuhi. 
Kendala-Kendala Penegakan Hukum Dalam Pelaksanaan Perlindungan Terhadap Korban Kekerasan Dalam Rumah Tangga dan bullying , yaitu:

a. Kekerasan dalam rumah tangga seringkali tidak dilaporkan ke pihak kepolisiaan, karena korban merasa malu untuk membuka persoalan rumah tangga kepada pihak lain;

b. Apabila perkara sudah ada pengaduan seringkali korban menarik kembali pengaduan dan bermaksud menyelesaikan perkara secara kekeluargaan;

c. Pengaruh social media mengakibatkan anak melakukan bullying.

Tujuan dilakukannya pengabdian kepada masyarakat ini adalah untuk mengetahui bagaimana perlindungan hukum terhadap korban KDRT menurut UU No 23 Tahun 2004 tentang Penghapusan KDRT dan Untuk mengetahui praturan Undang-Undang Republik Indonesia Nomor 23 Tahun 2002 Tentang perlindungan anak serta apa kendala-kendala penegakan hukum dalam pelaksanaan perlindungan terhadap korban kekerasan dalam rumah tangga dan kasus bullying terhadap anak.

\section{Metode Pelaksanaan}

Persiapan pengabdian masyarakat ini dilakukan pada bulan, Mei 2020 yang meliputi perijinan, pembuatan undangan online dan pembuatan materi edukasi.

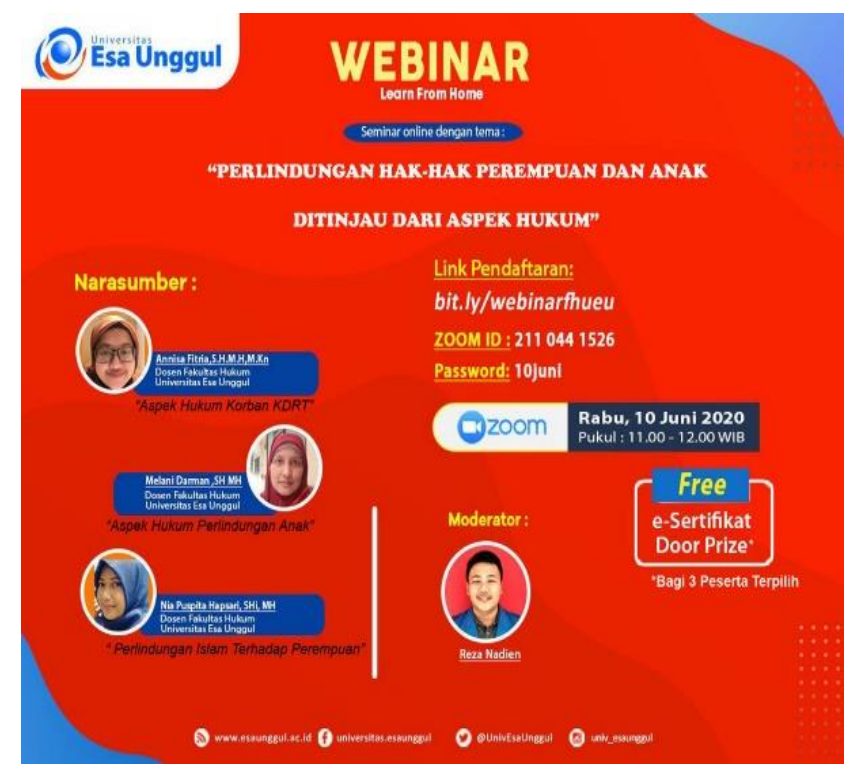

Materi edukasi terdiri dari pendahuluan mengenai Perlindungan Hak-Hak Perempuan dan Anak Ditinjau Dari Aspek Hukum, pembahasan dan solusi yang diberikan. Berikut adalah materi dalam Power Point yang kami sampaikan.

\section{Hasil dan Pembahasan}

Kekerasan dalam Rumah tangga dan Bullying terhadap anak baik itu secara fisik maupun mental memang masih menjadi kasus besar di Indonesia. sudah banyak memakan korban sampai dengan kematian. Hal itu amat sangat disayangkan , keluarga di dalam Undang-Undang Nomor 1 Tahun 1974 tentang Perkawinan dianggap sebagai suatu yang sacral ikatan untuk membentuk keluarga berdasarkan Ketuhanan Yang Maha Esa maka dari itu pernikahan harus lah dilandasi dengan kasih sayang dan cinta kasih. Anak merupakan generasi penerus bangsa yang harus diberikan pendidikan serta hidup yang layak tidak seorangpun boleh menyakiti anak terlebih sampai membuat anak trauma Kurangnya kesadaran dan juga ketidaktahuan atas adanya hukum yang dapat menjerak perbuatan diatas menyebabkan ada beberapa oknum melakukan KDRT dan juga bully terhadap anak. Melalui Pengabdian masyarakat ini diharapkan kesadaran dan memiliki sikap yang tegas jika diketemukan di dalam lingkungan kita ada korban KDRT dan juga Korban bullying anak agar bisa dilaporkan ke pihak berwajib dan para korban diberi kesembuhan yang baik.

Macam-Macam Tindak Pidana Kekerasan Dalam Rumah Tangga (KDRT)

a. Kekerasan Fisik Berupa tindakan kekerasan yang dilakukan dengan cara menyerang dengan menggunakan senjata dan yang diserang adalah fisik seseorang, yang dapat menyebabkan luka berat bahkan yang tidak dapat disembuhkan, dan kemungkinan dapat berakibat kematian.

b. Kekerasan Seksual Berupa tindakan kekerasan seksual yang perempuan menyerahkan dirinya meski dalam keadaan terpaksa dan dalam ancaman seseorang untuk melakukan hubungan suami istri.

c. Kekerasan Secara Psikologis Kekerasan psikis merupakan kekerasan yang dilakukan dengan penghinaan, merendahkan, mengekploitasi sehingga dapat mengakibatkan atau dampak yang ditimbulkan dari adanya kekerasan yaitu ancaman kekerasan.

d. Kekerasan Finansial Kekerasan yang dilakukan dengan cara mengeksploitasi, manipulasi, mengendalikan korban untuk bekerja tetapi dengan cara yang tidak baik dan memaksa, tidak menafkahi, atau korban sama sekali tidak diberikan ruang utnuk bekerja namun menelantarkannya.

Faktor-Faktor Penyebab Tindak Pidana Kekerasan Dalam Rumah Tangga (KDRT). Kaum perempuan merupakan kelompok social yang rentan mengalami kekerasan oleh seseorang yang sangat 
dekat dengannya yakni suaminya, ada beberapa factor mengapa terjadinya kekerasan dalam rumah tangga :

a. Berbicara Keras Berbicara keras merupakan satu factor yang harus di hindari, karena dapat memancing emosi pendengar karena merasa sakit hati, sehingga akan terjadi percekcokan. Sehingga antara suami dan istri harus mampu mengendalikan dan mengontrol emosi masing - masing. Karena emosi dapat memicu terjadinya kekerasan dalam rumah tangga.

b. Sifat Ego Salah satu penyebab terjadi nya kekerasan karena hanya ingin di dengarkan dan di ikuti maunya saja, sehingga membuat pasangan menjadi marah dan muncul lah perlakuan arogan dan semenah - menah terhadap istri/suami.

c. Ekonomi Factor penyebab yang sangat sering terjadi dalam kasus kekerasan dalam rumah tangga, dalam artian bahwa jika keadaan ekonomi dalam suatu keluarga masih labil atau masih belum mencukupi, maka setiap salah satu menginginkan sesuatu dan kebutuhan itu tidak terpenuhi disnilah akan muncul pertengkaran dan tidak bisa dipungkiri bisa terjadi kekerasan di dalamnya. Bukan hanya terkait keinginan dan kebutuhan seorang istri atau suami, tetapi terkait keikutsertaan suami atau istri dalam mengelola keuangan keluarga, salah satu pihak menginginkan adanya transparansi keuangan keluarga juga seringkali dapat memicu terjadinya kekerasan dalam rumah tangga. Oleh karena itu kemampuan suami yang pada umumnya di posisikan sebagai kepala keluarga harus mampu memenuhi nafkah dan kebutuhan keluarga serta harus mampu terbuka kepada istri terkait keuangan keluarga agar tidak terjadi kesalah pahaman.

d. Kekerasan Sebagai Alat Untuk Menyelesaiakan Konflik. Faktor ini merupakan factor juga sangat mempengaruhi, ketika ada kesalahpahaman, atau tidak tercapainya keinginan suami terhadap istri, bisa saja laki - laki yang cenderung memiliki kekuatan fisik diatas lebih kuat daripada perempuan, menggunakan kekuatan fisiknya untuk melukai, memukul istri agar mematuhi apa yang menajdi keinginannya. Hal ini membuktikan bahwa suami selalu menggunakan kekuatan fisiknya untuk menyelesaikan persoalan dalam rumah tangga.
Berbagai Dampak Terjadi Kekerasan Dalam Rumah Tangga (KDRT)

a. Rasa Takut

b. Perilaku Depresif

c. Perilaku Yang Tidak Lazim

d. Sakit Tanpa Penyebab

e. Dapat Menyakiti Dirinya Sendiri

f. Berdampak Juga Terhadap Anak

Contoh Kasus Yang Terjadi Di Indonesia :

1. Sumber

https $/ /$ nasional.okezone.com $/ \mathrm{read} / 2018 / 01 / 1$

2/337/1844191/5-kasus-kdrt-di-indonesia-

paling-miris-ada-yang-sampai-jual-istri

Seorang suami, di Surabaya, Jawa Timur tega menjual istrinya ke orang lain untuk digauli secara bersama-sama. Bahkan perbuatan tersebut sudah dilakukan sebanyak tiga kali. Ia memaksa istrinya melakukan hubungan intim bersama-sama dengan dua hingga tiga pria sekaligus termasuk dirinya.

2. Suami Tega Injak Perut Istri yang Sedang Hamil suami menginjak-injak perut istrinya yang sedang hamil tua. Kemudian bayi nya terpaksa lahir dan meninggal dunia.

3. Suami Bacok Istri 12 Kali hingga Tewas Lantaran cemburu kepada istrinya, seorang suami Kabupaten Musi Rawas nekat menghabisi nyawa istrinya dengan sadis.

Menteri Pemberdayaan Perempuan dan Perlindungan Anak, I Gusti Ayu Bintang Darmawati menjelaskan saat ini masih adanya kasus kekerasan pada perempuan dan anak di tengah pandemi Covid19. Dia menjelaskan terdapat 275 kasus kekerasan dewasa yang diantaranya 184 adalah korban kekerasan dalam rumah tangga (KDRT). Berdasarkan data Simponi (Sistem Informasi Online) pemberdayaan perempuan dan perlindungan anak, data simponi pemberdayaan perempuan dan anak tanggal 2 Maret-25 April 2020 tercatat, terdapat 275 kasus kekerasan dewasa dengan total korbannya sebanyak 277, diantaranya 184 adalah korban KDRT. Kemudian juga terdapat kasus kekerasan pada anak dengan memakan korban 407 anak dan terdiri dari 368 kasus. Dia menjelaskan anak-anak dan perempuan lebih banyak jadi korban yaitu sebanyak 300 anak perempuan.

Mekanisme Berdasarkan Sistem Peradilan Pidana (Pendekatan Penal). Proses penyelesaian yang dimaksudkan adalah melalui tahap - tahap berikut yakni:

1. Tahap penyelidikan/penyidikan Tahap yang dilakukan ditingkat kepolisian. Kepolisian, dengan tugas utama menerima laporan dari pihak - pihak yang merasa dirugikan, 
melakukan penyelidikan/penyiikan terhadap suatu tindak pidana, melakukan penyaringan terhadap kasus - kasus yang dapat dilimpahkan kepada kejaksaan, dan melaporkan hasil penyidikan.

2. Tahap Penuntutan Kejaksaan dengan mengemban tugas utama, menyaring kasus kasus yang dapat dilimpahkan ke kejaksaan, menyiapkan berkas penuntutan, melakukan penuntutan, dan melaksanakan putusan pengadilan.

3. Tahap Persidangan Tahap persidangan yang ditangani oleh lembaga yang berwenang yakni adalah Pengadilan. Pengadilan dengan mengamban kewajiban untuk menegakkan hukum, melindungi apa yang menjadi hak dan kewajiban dari terdakwa, saksi, maupun korban pada saat sidang sedang berjalan, memeriksa kasus dengan baik, cermat, dan teliti sehingga tidak akan ada kekeliruan, dan memberikan putusan yang dipandang adil untuk semua pihak yang terkait.

4. Lembaga Pemasyarakatan Setelah ada putusan dari pengadilan, maka selanjutnya pelaku dilimpahkan ke LAPAS atau Lembaga Pemasyarakatan yang memiliki fungsi untuk menjalankan putusan pengadilan terhadap pelaku untuk dilakukan pemenjaraan terhadap narapidana.

\section{KETENTUAN PIDANA Pasal 44}

(1) Setiap orang yang melakukan perbuatan kekerasan fisik dalam lingkup rumah tangga sebagaimana dimaksud dalam Pasal 5 huruf a dipidana dengan pidana penjara paling lama 5 (lima) tahun atau denda paling banyak Rp15.000.000,00 (lima belas juta rupiah).

(2) Dalam hal perbuatan sebagaimana dimaksud pada ayat (1) mengakibatkan korban mendapat jatuh sakit atau luka berat, dipidana dengan pidana penjara paling lama 10 (sepuluh) tahun atau denda paling banyak Rp30.000.000,00 (tiga puluh juta rupiah).

(3) Dalam hal perbuatan sebagaimana dimaksud pada ayat (2) mengakibatkan matinya korban, dipidana dengan pidana penjara paling lama 15 (lima belas) tahun atau denda paling banyak Rp45.000.000,00 (empat puluh lima juta rupiah).

(4) Dalam hal perbuatan sebagaimana dimaksud pada ayat (1) dilakukan oleh suami terhadap isteri atau sebaliknya yang tidak menimbulkan penyakit atau halangan untuk menjalankan pekerjaan jabatan atau mata pencaharian atau kegiatan sehari-hari, dipidana dengan pidana penjara paling lama 4 (empat) bulan atau denda paling banyak Rp5.000.000,00 (lima juta rupiah).
Mekanisme

Penyelesaian

Secara

Kekeluargaan (Non Sistem Peradilan Pidana/Non Penal)
a. Sepakat untuk menempuh proses mediasi
b. Memahami masalah - masalah
c. Membangkitkan pilihan - pilihan pemecahan masalah
d. Mencapai kesepakatan
e. Melaksanakan kesepakatan

Dalam proses tahapan penyelesaian kasus kekerasan dalam rumah tangga (KDRT) dengan jalur non penal yang terpenting harus ada kesepakatan antara korban dan pelaku untuk melakukan mediasi, agar kedua pihak dengan mudah memahami masalah - masalah yang menjadi kejanggalan sehingga muncul pilihan untuk memecahkan masalah baik kerugian yang dialami korban maupun pelaku yang dibicarakan dalam satu forum sehingga dapat mencapai kesepakatan yang disepakati bersama dan dianggap adil untuk kedua pihak.

Penyelesaian kasus kekerasan dalam rumah tangga (KDRT) dengan jalur non penal juga memiliki dasar hukum. Proses penyelesaian perkara kekerasan dalam rumah tangga (KDRT) melalui jalur non penal berdasarkan pada Surat Kapolri No. Pol : B./3022/XII/2009/ Sdeops tgl. 14 Desember 2009 tentang penanganan kasus melalui ADR, yaitu terhadap tindak pidana, dengan kerugian kecil dan disepakati oleh para pihak yang berperkara, melalui prinsip musyawarah mufakat, serta menghormati norma hukum social/adat dan berasaskan keadilan bagi para pihak.

HAK-HAK KORBAN- Pasal 50

Korban berhak mendapatkan:

a. perlindungan dari pihak keluarga, kepolisian, kejaksaan, pengadilan, advokat, lembaga sosial, atau pihak lainnya baik sementara maupun berdasarkan penetapan perintah perlindungan dari pengadilan;

b. pelayanan kesehatan sesuai dengan kebutuhan medis;

c. penanganan secara khusus berkaitan dengan kerahasiaan korban;

d. pendampingan oleh pekerja sosial dan bantuan hukum pada setiap tingkat proses pemeriksaan sesuai dengan ketentuan peraturan perundang-undangan; dan

e. pelayanan bimbingan rohani.

PERLINDUNGAN- Pasal 16

(1) Dalam waktu 1 x 24 (satu kali dua puluh empat) jam terhitung sejak mengetahui atau menerima laporan kekerasan dalam rumah tangga, kepolisian wajib segera memberikan perlindungan sementara pada korban. 
(2) Perlindungan sementara sebagaimana dimaksud pada ayat (1) diberikan paling lama 7 (tujuh) hari sejak korban diterima atau ditangani.

(3) Dalam waktu 1 x 24 (satu kali dua puluh empat) jam terhitung sejak pemberian perlindungan sebagaimana dimaksud pada ayat (1), kepolisian wajib meminta surat penetapan perintah perlindungan dari pengadilan.

Pasal 17

Dalam memberikan perlindungan sementara, kepolisian dapat bekerja sama dengan tenaga kesehatan, pekerja sosial, relawan pendamping, dan/atau pembimbing rohani untuk mendampingi korban.

PEMULIHAN KORBAN- Pasal 39

Untuk kepentingan pemulihan, korban dapat memperoleh pelayanan dari:
a. tenaga kesehatan;
b. pekerja sosial;
c. relawan pendamping; dan/atau
d. pembimbing rohani.

\section{Kesimpulan}

Setelah melakukan pengabdian masyarakat banyak juga masyarakat yang belum mengetahui Peraturan mengenai kekerasan dalam rumah tangga dan peraturan perlindungan anak. Banyaknya disekitar kita kasus -kasus KDRT dan bullying anak yang sampai saat ini solusi efektif nya masih belum berjalan dengan baik. Jika menjadi korban dari KDRT ataupun bullying sangat dianjurkan untuk melapor kepada pihak berwajib, tetapi sebelumnya bisa terlebih dahulu melapor kepada orangtua, kerabat, tetangga atau pihak - pihak yang dapat membantu menyelesaikan masalah. Jangan pernah takut untuk melapor kepada pihak berwajib karena pihak berwajib pasti akan membantu untuk memutus rantai KDRT dan bullying.

Perlunya kesadaran hukum terhadap masyarakat. Perlunya aparat penegak hukum bahkan pemerintah daerah setepmat untuk turut serta memberantas kasus KDRT dan bullying anak agar tidak terjadi. Misalkan dengan datang ke sekolahsekolah untuk memberikan sosialisasi mengenai bahaya bullying atau melakukan sidak di sekolah.

Diperlukan Rancangan Undang Undang Perlindungan anak menjadi Undang Undang Perlindungan anak menggantikan peraturan yang lama.

\section{Daftar Pustaka}

Adami Chazawi. (2002). Pelajaran Hukum Pidana Bagian 1, Jakarta: PT. RajaGrafindo Persada.
Al Wisnubroto. (2002). Praktek Peradilan Pidana Proses Persidangan Perkara Pidana, Jakarta: PT. Galaxy Puspita Mega.

Fatahillah A. Syukur. (2011). Mediasi Perkaara KDRT (Kekerasan Dalam Rumah Tangga) Teori dan Praktek Di Pengadilan Indonesia, Bandung: CV. Mandar Maju.

Fathul Djannah dkk. (2003). Kekerasan Terhadap Istri, Yogyakarta: Lkis.

Guse Prayudi. (2009). Berbagai Aspek Tindak Pidana Kekerasan Dalam Rumah Tangga, Sukabumi: Merkid Press.

Moerti Hardiati Soeroso. (2010). Kekerasan Dalam Rumah Tangga Dalam Perspektif YuridisViktimologis, Jakarta: Sinar Grafika Offset.

Undang- Undang Nomor. 23 Tahun 2004 tentang Penghapusan Kekerasan Dalam Rumah Tangga.

Undang- Undang Nomor 35 tahun 2014 tentang Perubahan Atas Undang-Undang Nomor 23 tahun 2002 tentang Perlindungan Anak.

Kitab Undang-Undang Hukum Pidana.

Undang-Undang Nomor 1 Tahun 1974 Tentang Perkawinan. 